Article

Moritz Scherleitner* and Tomi Viitala

\title{
EU State Aid Rules as a Means of Promoting Equity within International Taxation - With a focus on inter-taxpayer equity in light of the Apple case
}

https://doi.org/10.2478/ntaxj-2021-0003

Received Dec 22, 2020; accepted May 28, 2021

Keywords: Inter-taxpayer equity; EU tax law; State aid; Apple; fairness

"The Commission stands fully behind the objective that all companies should pay their fair share of tax. If Member States give certain multinational companies tax advantages not available to their rivals, this harms fair competition in the EU."

Statement by Executive Vice-President Margrethe Vestager following the GC's judgment on the Apple tax State aid case in Ireland

\section{Introduction}

We can safely assume that the person on the street regards an MNE's effective tax rate of $0.005 \%$ on its European profits as unfair. ${ }^{1}$ Ultimately, his or her effective tax rate is likely considerably higher. Neither will such a person be happy to hear that almost $40 \%$ of MNE profits have been shifted into "tax havens." 2 That is a lot of money, the per-

\footnotetext{
*Corresponding Author: Moritz Scherleitner: LL.D., MSc. (WU), Assistant Professor, Tax Law, Aalto University Tomi Viitala: D.Sc., tax partner at Deloitte Finland. Email: tomi.viitala@deloitte.fi
}

The authors thank Linda Sydänmaanlakka for discussing a draft version of the article and an unknown peer reviewer for his/her comments. In addition, the first author thanks Suomen veromiehetFinlands beskattningsmän ry for their financial support. All opinions and errors are solely the authors'.

1 Commission, State aid: "Ireland Gave Illegal Tax Benefits To Apple Worth up to $€ 13$ Billion," available at https://ec.europa.eu/commission/presscorner/detail/en/IP_16 2923 (accessed 12.12.2020).

2 id. son will think, and it is I or my children who will have to fill the emerging holes in the budget.

To what extent this logic holds true in reality is hard to say. MNEs' aggressive tax positions are often the tax benefits that states offer-out of pure self-interest. ${ }^{3}$ So the person on the street on a small island in the Caribbean will have a different view about the matter from that of someone living in a European welfare state. Yet, in the aftermath of the financial crisis, the public outcry of the latter was loud ${ }^{4}$-and politicians reacted. ${ }^{5}$ As stated in the final dec-

3 Compare, for example, H. J. Ault, W. Schön, and S. Shay, Base Erosion and Profit Shifting: A Roadmap for Reform, 68 Bull Intl. Taxn. 5/6 (2014) Journals IBFD, who regard "MNE tax avoidance [to be] just the flipside of harmful tax competition.” Schön, for instance, has described the OECD/G20 BEPS Project as some sort of revival of the OECD, Report on Harmful Tax Competition: An Emerging Global Issue (OECD 1998) [hereinafter OECD Harmful Tax Competition]; Conclusions of December 1, 1997, Ecofin Council Meeting on taxation policy-resolution of December 1, 1997, on a code of conduct for business taxation, OJ C 2, 6 January 1998, with the difference being that now MNEs, instead of states, are in the focus. See, e.g., the interview with W. Schön, „Leichter auf die Anklagebank“, EY TAX\&LAW Magazine 02/2014, available at https://www.tax.mpg.de/fileadmin/TAX/docs/TL/WS/EY_B EPS.pdf (accessed 2. June 2020). Certainly, taxpayers may also achieve crossborder tax savings that are not "offered" by the involved states but create some sort of unintended double lack of taxation. See further F.D. Martínez Laguna, Abusfor e and Aggressive Tax Planning: Between OECD and EU Initiatives-The Dividing Line between Intended and Unintended Double Non-Taxation, 9 World Tax J. 2, secs. 2.2.-2.3. (2017); M. Helminen, General Report, in The notion of Tax and the Elimination of International Double Taxation or Double Non-Taxation sec. 4.1. (IFA Cahiers vol. 101a, Sdu Fiscale \& Financiele Uitgevers 2016), Books IBFD.

4 According to the Commission: "Apple only paid an effective corporate tax rate that declined from $1 \%$ in 2003 to $0.005 \%$ in 2014 on the profits of Apple Sales International". See Commission, State aid: Ireland gave illegal tax benefits to Apple worth up to $€ 13$ billion, available under: https://ec.europa.eu/commission/presscorner/detail/en/IP_16 2923 (accessed May 25, 2020).

5 Compare Y. Brauner, BEPS: An Interim Evaluation, 6 World Tax J. 2, sec. 1 (2014), Journal Articles \& Papers IBFD, naming, as an example, the newspaper articles by C. Duhigg and D. Kocieniewski, 
laration of the 2013 G20 summit in St. Petersburg, “[i]n a context of severe fiscal consolidation and social hardship, in many countries ensuring that all taxpayers pay their fair share of taxes is more than ever a priority. Tax avoidance, harmful practices and aggressive tax planning have to be tackled." 6

What started in 2013 with the OECD Base Erosion and Profit Shifting (BEPS) Project ${ }^{7}$ is meant to peak in a "consensus-based multilateral solution to overhaul the international tax system." ${ }^{8}$ As part of these wider efforts, the commission has also launched various high-profile state aid proceedings ${ }^{9}$ that should recover taxes from a number of MNEs that benefitted from "sweetheart-deals" with cer-

How Apple Sidesteps Billions in Taxes, The New York Times (April 28, 2012); J. Drucker, Google Revenues Sheltered in No-Tax Bermuda Soar to \$10 Billion, Bloomberg (10 Dec. 2012); and R. Waters, Microsoft's Foreign Tax Planning Under Scrutiny, Financial Times (7 June 2011). See also OECD, What the BEPS are we talking about?, available at http://www.oecd.org/ctp/what-the-beps-are-we-talkingabout.htm (accessed May 25, 2020); On the importance of negative media coverage as an impetus for the OECD/G20 BEPS Project, see A. Christians and S. Shay, General Report, in Assessing BEPS: Origins, Standards, and Responses, sec. 2.1. (IFA Cahiers vol. 102a, Sdu Fiscale and Financiele Uitgevers 2017), Books IBFD.

6 G20 Leaders ' declaration para. 50, St. Petersburg (2013).

7 Starting with the OECD, Addressing Base Erosion and Profit Shifting (OECD Publishing 2013) and culminating in the final reports on 15 action items delivered in 2015. Including further materials, they are available under https://www.oecd.org/tax/beps/beps-actions/ (accessed 22 May 2020).

8 OECD Secretary-General Angel Gurría, as quoted under http://www.oecd.org/tax/beps/international-community-renewscommitment-to-multilateral-efforts-to-address-tax-challenges-fromdigitalisation-of-the-economy.htm (accessed 9 July 2020).

9 E.g., Amazon in Luxembourg (SA.38944), Apple in Ireland (SA.38373), Starbucks in the Netherlands (SA.38374 (2014/C ex 2014/NN), Fiat in Luxembourg (SA.38375) and Engie in Luxembourg (SA.44888). See in more detail, e.g., E. Traversa and A. Flamini, Fighting Harmful Tax Competition through EU State Aid Law: Will the Hardening of Soft Law Suffice? 14 Eur. State Aid Law Q. 3, pp. 323-324 (2015); P. Lampreave, Harmful Tax Competition and Fiscal State Aid: Two Sides of the Same Coin?, 59 Eur. Taxn. 5 (2019); A. Giraud and S. Petit, Tax Rulings and State Aid Qualification: Should Reality Matter? 16 Eur. State Aid Law Q. 2 (2017); J. Monsenego, Selectivity in State Aid Law and the Methods for the Allocation of the Corporate Tax Base p.4, (Kluwer 2018); P. Wattel, Stateless Income, State Aid and the (Which?) Arm's Length Principle, 44 Intertax 11, p. 791 (2016); P. Wattel, Interaction of State Aid, Free Movement, Policy Competition and Abuse Control in Direct Tax Matters, 5 World Tax J. 1, pp. 135-140 (2013). See R. Luja, State Aid Benchmarking and Tax Rulings: Can We Keep It Simple? in State Aid Law and Business Taxation p. 124 (I. Richelle, W. Schön \& E. Traversa eds., Springer 2016). MPI Studies in Tax Law and Public Finance. tain tax authorities; ${ }^{10}$ among them is the above-mentioned MNE with an effective tax rate of $0.005 \%$ : Apple.

State aid is defined in Article 107(1) of the Treaty on the Functioning of the European Union (TFEU) as prohibiting "any aid granted by a Member State or through State resources in any form whatsoever which distorts or threatens to distort competition by favoring certain undertakings or the production of certain goods shall, in so far as it affects trade between member states.” The application of state aid rules on tax measures is not at all a new phenomenon but already happened in $1974 .{ }^{11}$ Thus, the CJEU recognized rather early that a lower tax bill can be state aid as much as paying a subsidy. ${ }^{12}$ Nevertheless, the field, often referred to as fiscal state aid, was regarded to have been relatively quiet. ${ }^{13}$ With the start of the commission's 2014 offensive, this definitely changed. The attention for this area grew starkly because of the almost absurdly high sums that are at stake in these proceedings. ${ }^{14}$

The general objective of state aid rules is to promote fair competition between enterprises in the EU. As a result of the increased competition neutrality, the functioning of the internal market should be improved. Leaving this and dogmatic legal access points to the topic of fiscal state aid untouched, ${ }^{15}$ this article aims to provide for a new perspective by asking whether state aid rules can also promote fairness in European taxation. In view of the statements of Commissioner Vestager, it can also be assumed that they are meant to do so. In 2016, the latter said:

For me, that issue of fairness is the most important message from our enforcement of state aid rules in tax cases and it is my duty as Commissioner for competition to make sure that the rules apply

10 B. Vos, State Aid, Taxation and Transfer Pricing: Illegal Fiscal State Aid Granted to Starbucks? 27 EC Tax Rev. 2 (2018)

11 IT: ECJ, 2 July 1974, Italian Republic v Commission of the European Communities, [1974] Case 173/73, ECLI:EU:C:1974:71.

12 See, under reference to even earlier tendencies in the CJEU's jurisprudence, J. Kokott, Steuerrecht und unionsrechtlicher Beihilfebegriff, in Europäisches Steuerrecht p. 536 (M. Lang ed., DStJG Tagungsband 41, 2018).

13 S. Douma, State Aid and Direct Taxation, in European Tax Law 7th ed. (B.J.M. Terra \& P.J. Wattel eds., Kluwer 2018)

14 In the Apple case, a recovery of EUR 13 billion is at stake.

15 For generally and including many further references, see further: J. Englisch, Das Beihilfe Verbot im Steuerrecht, in Europäisches Steuerrecht (J. Englisch and H. Schaumburg eds., Otto Schmidt 2015); J. Kokott, Steuerrecht und unionsrechtlicher Beihilfebegriff, in Europäisches Steuerrecht p. 541 (M. Lang ed., Otto Schmidt 2017); S. Douma, State Aid and Direct Taxation, in European Tax Law 7th ed. (B. J. M. Terra and P.J. Wattel eds., Kluwer 2018), or the contributions in State Aid Law and Business Taxation (I. Richelle, W. Schön, E. Traversa eds, Berlin and Heidelberg: Springer Verlag 2016). 
in a fair manner to any company that does business in the EU's single market- regardless of size, sector or nationality. ... Responsible taxpayers don't have to pick up the bill left by companies that avoid tax. And the public gains confidence that there's a fair chance for everyone, not just for a few well connected companies $^{16}$

Inquiring into this issue is more than an academic hobby. While it takes quite some effort to build up an analytical framework against the background of which the analysis can be executed and admitting that the notion is still very hard to grasp, let alone, to measure, there are still important aspects that seem to make investigations such as this one worth conducting. In fact, our tax systems are built on voluntary compliance, and the extent of this, in part, depends on people's opinions on the fairness of taxation. Compliance was found to decrease when the perception that the tax system is unfair increases. ${ }^{17}$ To see how much that matters, consider that according to some estimates, tax evasion may even amount to 850 billion to 1 trillion USD per year in the EU alone. ${ }^{18}$

Section 2 will provide a minimalist discussion of the notion of fairness in corporate taxation. Thereafter, an analytical framework (section 3) will be set up against which the Apple case, as decided by General Court of the European Union (GC), will be tested. The aim is to see how close the case came to a stylized theoretical optimum of intertaxpayer equity that can be reached in the EU with distinct tax systems. To account for the inevitable existence of trade-offs between different tax policy goals, we will also reflect on the reasons that explain why the GC has not always gone that far-and thus show the limits of the law, set by reality, that the person on the street needs to accept in the current tax landscape (sections 4-6). It is worth mentioning upfront that the article does not discuss Irish residency rules-despite their being an integral part of Ap-

16 As worked out in A. Pirlot, The Vagueness of Tax Fairness: A Discursive Analysis of the Commission's 'Fair Tax Agenda,' 48 Intertax 4, in section 2.2 (2020), with reference to a 2016 speech of Commissioner Vestager delivered at the Copenhagen Business School.

17 There is evidence for such behavior. See, e.g., E. Kirchler, E. Hoelzl and I. Wahl, Enforced Versus Voluntary Tax Compliance: The "Slippery Slope" Framework, 29 J. Econ. Psychol. pp. 210-225 (2008); the attitude toward taxation has also been named one of the challenges for domestic resource mobilization in developing countries, and the fairness of the tax structure was mentioned as being among the factors that have an influence in this regard. See, e.g., R. M. Bird, Administrative Dimensions of Tax Reform, 10 Asia-Pac. Tax Bull. 3, sec. 2.1 (2004). 18 R. Murphy, The European Tax Gap, Tax Research UK, available at www.taxresearch.org.uk/Documents/EUTaxGapJan19.pdf (accessed 10 July 2020); note, however, that these figures are not undisputed among economists. ple's tax planning strategy. Apart from the fact that these rules have already been changed, ${ }^{19}$ they have-to the surprise of some ${ }^{20}$-not been challenged by the commission in the Apple case.

\section{Theory: Equity in (Corporate) Taxation ${ }^{21}$}

The debate on equity in taxation has been going on for more than 2,000 years. ${ }^{22}$ In short, it is about fairness in sharing the tax burden among taxpayers (inter-taxpayer equity) ${ }^{23}$ and sharing tax revenues among nations (inter-

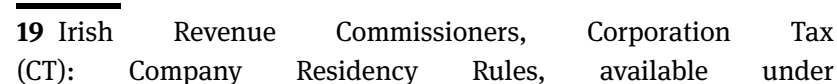
https://www.revenue.ie/en/companies-and-charities/corporationtax-for-companies/corporation-tax/company-residency-rules.aspx (accessed 8. Mar. 2021).

20 S. Daly, Case Note on Apple: An Unexpected Outcome, available under https://taxatlincolnox.wordpress.com /2020/07/16/case-noteon-apple-an-unexpected-outcome/ (accessed 13. Aug. 2020); J. Monsenego, Some Observations on the Apple Case, available at http://competitionlawblog.kluwercompetitionlaw.com/2020/08 /04/some-observations-on-the-apple-case/?doing_wp_cron= 1596530271.7670359611511230468750\&print=print. (accessed August 13, 2020); see on the Irish rules, e.g., Mason and S. Daily, State Aid: The General Court Decision in Apple, 99 Tax Notes Int'l 1326 et seq (2020).

21 The core point made in this section is based on a more detailed elaboration in M. Scherleitner, Addressing Tax Arbitrage with Hybrid Financial Instruments: A Multidisciplinary Study and Proposal for Developed and Developing Countries sec. 3.2.1.2. (IBFD 2020).

22 K. Vogel, Worldwide vs. Source Taxation of Income-A Review and Re-Evaluation of Arguments (Part I), 16 Intertax 8/9, p. 216 (1988).

23 See, e.g., the relevant discussion and references provided for below and, further, including many references, e.g.: B. Galle, Tax Fairness, 65 Wash. and Lee L. Rev., p. 1327 (2008); J. Lang, \& 4 Rechtsstaatliche Ordnung des Steuerrechts, in Steuerrecht paras. 60123 (20th ed., K. Tipke and J. Lang eds., Otto Schmidt 2010); D.G. Duff, Tax Fairness and the Tax Mix p. 2 (The Foundation of Law, Justice and Society 2009); and H.P. Gaisbauer, G. Schweiger and C. Sedmak, Outlining the Field of Tax Justice, in Philosophical Explorations of Justice and Taxation ch. 1 (H.P. Gaisbauer, G. Schweiger \& C. Sedmak eds., Springer 2015); I. J. J. Burgers and I. J. Mosquera Valderrama, Fairness: A Dire International Tax Standard with No Meaning?, 45 Intertax 12, p. 768 (2017); M. Stewart, The Tax State, Benefit and Legitimacy, in Studies in the History of Tax Law pp. 483-515 (P. Harris and D. de Cogan eds., Hart Publishing 2015); F. Debelva, Fairness and International Taxation: Star-Crossed Lovers?, 10 World Tax J. 4, sec. 1. (2018), Journal Articles and Papers IBFD; at a fundamental level see, e.g., A. Smith, An Inquiry into the Nature and Causes of the Wealth of Nations pp. 825-906 (Oxford University Press 1976), whose original work appeared in 1776 and laid the ground for equity being nowadays widely accepted as being one of the guiding principles of company taxation 
nation equity). ${ }^{24}$ This contribution will, as mentioned, focus on the first dimension.

Before we are able to do so, some issues require a brief preliminary discussion. First, while fairness underpins income taxation, ${ }^{25}$ a consensus in "paraphrasing" 26 it is unachievable given the great importance of personal values

(the other ones being efficiency and administrability). See, in this regard, e.g., C. Brokelind, The Evolution of International Income Tax Law Applied to Global Trade, 34 Intertax 3, sec. 4 (2006); Referring to various philosophical forerunners of Smith, id., see J. Frecknall-Hughes, The Theory, Principles and Management of Taxation p. 21 (Routledge 2015); See further Pirlot, supra n. 16; Y. Brauner and M.J. McAhon, The Proper Tax Base: Structural Fairness from an International and Comparative Perspective - Essays in Honour of Paul McDaniel, Series on International Taxation no. 39 (Y. Brauner and M. J. McMahon Jr. eds, Kluwer Law International 2012); D. Duff, Tax Fairness and the Tax Mix, FLJS (2008); J. C. Fleming, R. J. Peroni and S. E. Shay, Fairness in International Taxation: The Ability-to-Pay Case for Taxing Worldwide Income, 5 Fla. Tax Rev. 4, 299-354 (2001); S. J. C. Hemels, Fairness: A Legal Principle in EU Tax Law?, in Principles of Law: Function, Status and Impact in EU Tax Law, GREIT Series 413-437 (C. Brokelind ed., IBFD 2014); P. B. W. L. Lamberts, Fair Taxation: Truth Is in the Eye of the Beholder, 45 Intertax 1, 49-53 (2017); S. M. Sheffrin, Tax Fairness and Folk Justice (Camebridge University Press 2013).

24 See, at a fundamental level, e.g., G. von Schanz, Zur Frage der Steuerpflicht, 9 Finanzarchiv (1892); League of Nations, Report on Double Taxation: Document E.F.S.73.F.19. (April 15, 1923) and the following reports made prior to the release of the first Model Convention including a commentary thereto, which is the League of Nations, Double Taxation and Tax Evasion C.562.M.178.1928.II (October 22-31, 1928); League of Nations, Double Taxation and Tax Evasion: Report $C$. 216. M. 85 (League of Nations 1927); R. A. Musgrave and P. B. Musgrave, Inter-nation equity, in Modern Fiscal Issues: Essays in Honor of Carl S. Shoup p. 68 (R. M. Bird and J. G. Head eds., University of Toronto Press 1972); for discussions on this notion, see, including many further references, e.g.: Vogel, supra n. 22; A. J. Eason, International Tax Reform and the Inter-Nation Allocation of Tax Revenue p. 20 (Victoria University Press 1991); N.H. Kaufman, Fairness and the Taxation of International Income, 29 Law and Policy Intl. Bus. 2, pp. 173-176 (1998); R.S. Avi-Yonah, Globalization, Tax Competition, and the Fiscal Crisis of the Welfare State, 113 Harv. L. Rev. 7, pp. 1,649-50 (2000); A.H. Rosenzweig, Defining a Country's 'Fair Share' of Taxes, 42 Fla. State Univ. Law Rev., pp. 405-416 (2015); K. Brooks, Inter-Nation Equity: The Development of an Important but Underappreciated International Tax Value, in Tax Reform in the 21st Century (R. Krever and J. G. Head eds., Kluwer Law 2008); J. Li, Improving inter-nation equity through territorial taxation and tax sparing, in Globalization and its tax discontents: Tax policy and international investments. Essays in honour of Alex Easson p. 119 (A. J. Cockfield. ed., University of Toronto Press 2010); C. Peters, On the Legitimacy of International Tax Law sec. 4.2.2. (IBFD 2014).

$25 \mathrm{~K}$. Holmes, The Concept of Income - A multidisciplinary analysis $\mathrm{p}$. 14 (IBFD 2000), Books IBFD.

26 As indicated to be the adequate word in Vogel, supra n. 22, at p. 393. involved in the discussion. ${ }^{27}$ Second, and in a related way, the traditional way of assessing fairness between taxpayers by focusing on well-known notions of horizontal equity (i.e., equals should be treated alike) ${ }^{28}$ and vertical equity (i.e., an appropriate distinction should be made in respect of the treatment of people who are not alike ${ }^{29}$ is hardly undisputed..$^{30}$ Nevertheless, it is fair to say that horizontal equity matters in practice. As argued by Lindsay, it "is a fairness norm useful for structuring compromises between people who disagree about ideal principles of tax justice or about the empirical consequences of tax policy". ${ }^{31}$ What is more, taxpayers tend to view more horizontally equitable tax policies as more legitimate. ${ }^{32}$ As mentioned above, perceptions of a tax system's unfairness can even go in hand with taxpayers' being less inclined to comply with it. ${ }^{33}$ As a

27 Compare, e.g., R. A. Musgrave, Horizontal Equity, Once More, 43 Natl Tax J., pp. 114-117 (1990) [hereinafter Musgrave Horizontal Equity], who, after reviewing key theories of distributive justice, indicates his doubts as to their capability of being ranked in an objective fashion because values are involved about which individuals' opinions may differ. A consensus view on what is fair may also change with time; see E. R. A. Seligman, Essays in Taxation 1 (Macmillan 1895); and Holmes, supra n. 25, at p. 15. See also Gaisbauer, Schweiger and Sedmak, supra n. 23, ch. 1. See further J. Alm and B. Torgler, Culture differences and tax morale in the United States and Europe, $27 \mathrm{~J}$. Econ. Psychol. 2, pp. 224-246 (2006), who indicate that tax morale differs significantly and systematically across countries.

28 J. R. Repetti and D. M. Ring, Horizontal Equity Revised, 13 Fla. Tax Rev. 3, p. 136 (2013), referring to R. A. Musgrave, The Theory of Public Finance p. 113 (McGraw-Hill 1959); and L. Kaplow, Horizontal Equity in Search of a Principle, 42 Natl. Tax J. 2, pp. 140-141 (1989).

$29 \mathrm{id}$.

30 To be clear, there is a substantial discussion on whether or not horizontal equity itself should guide tax policy. Some disagree and invoke some "higher" distributional theory to which tax policy should contribute while others do attach a separate value to this notion. See, on the issue, e.g., Repetti and Ring, supra n. 28, at, pp. 135-155; L. Murphy and T. Nagel, The Myth of Ownership: Taxes and Justice (Oxford University Press 2002); K.A. Kordana and D.H. Tabachnik, Tax and the Philosopher's Stone, 89 Va. L. Rev., pp. 647-678 (2003); Repetti and Ring, supra n. 28; D. Elkins, Horizontal Equity as a Principle of Tax Theory, 24 Yale Law and Policy Review 1, pp. 43-90 (2006); I. K. Lindsay, Tax Fairness by Convention: A Defense of Horizontal Equity, 19 Fla. Tax Rev. 2, pp. 79-119 (2016). P. R. McDaniel and J. R. Repetti, Horizontal Equity and Vertical Equity: The Musgrave/Kaplow Exchange, 1 Fla. Tax Rev. 10 (1993).

31 id., at p. 85.

32 id., at pp. 111 and the following discussion pp. 112-115. In addition, horizontal equity may be a focal point for bargaining in tax reforms. See Id., at p. 111 and the following discussion at pp. 115-118.

33 There is evidence for such behavior. See, e.g., Kirchler, Hoelzl and Wahl, supra n. 17; J. C. Baldry, Income Tax Evasion and the Tax Schedule: Some Experimental Results, 43 Public finance (1987); F. A. Cowell, Tax Evasion and Inequity, 13 J. Econ. Psychol. (1992) for a literature review on the issue, see M. Wenzel, Tax Compliance and the Psychology 
result-and in relative ignorance of powerful voices to the contrary-this article will deem the promotion of horizontal equity as increasing fairness. ${ }^{34}$

The next challenges lie in how to measure when people are equal and when they are not. Two notions are traditionally relied on in this respect: The principle of ability to pay and the benefits principle. The former focuses on the economic capacity of a taxpayer and demands that taxation should reduce each taxpayer's welfare by an equal amount. ${ }^{35}$ The latter, on the other hand, looks at the benefits a person has received from the public hand and calls for those who have received more to pay more in taxes. ${ }^{36}$ Both principles have done their part in forming the international tax system. ${ }^{37}$ For this article, the principle of abil-

of Justice, in Taxing Democracy p. 48-54 (V. Braithwaite ed., Ashgate 2002). Compare also the discussion and references provided for in: $F$. Debelva, supra n. 23, at sec. 1; and the discussion and further references provided for in Scherleitner, supra n. 21, at sec. 3.2.1.2. It very much seems that horizontal equity considerations are of relevance in this context. For instance, it was held that if a group perceives its tax burden to be heavier than that of another group, tax compliance is more likely to decrease within the former group. Kirchler, Hoelzl, and Wahl, supra n. 17, at sec. 3.7.; and Wenzel, supra n. id, at pp. 49-50, referring to, e.g., M. W. Spicer and L. A. Becker, Fiscal Inequity and Tax Evasion: An Experimental Approach, 33 Natl. Tax J. 2, pp. 171-175 (1980), but also to other studies that did not find such an effect.

34 See, again, Lindsay, supra n. 30, at pp. 111-118, who underscore the fact that taxpayers tend to view more horizontally equitable tax policies as more legitimate. In addition, horizontal equity may be a focal point for bargaining in tax reforms; see, for a more differentiated discussion on this issue, Pirlot, supra n. 16, at sec. 4, who argues plausibly that the perception of increasing fairness may, in the long run, make taxpayers reevaluate their position if the positive social changes they expect from the relevant action do not occur.

35 See Murphy and Nagel, supra n. 30, in ch. 2 for a discussion of different understandings of the principle of ability to pay, including criticisms. See also Kordana and Tabachnik, supra n. 30, at p. 661. The notion goes back to the "equal sacrifice" principle articulated by J. S. Mill, Principles of Political Economy p. 622 (Gutenberg EBook 2009) pursuant to which all community members should give up the same, i.e., neither more nor less inconvenience should be felt by one taxpayer over another when contributing their share. See, for a discussion, also W. Schön, International Tax Coordination for a Second-Best World (Part I), 1 World Tax J. 1 (2009).

36 This idea goes back to T. Hobbes, Leviathan p. 213 (Green Dragon 1651), who writes, "[W]hen the Impositions are layd upon those things which men consume, every man payeth Equally for what he useth." See, for a more detailed elaboration on the issue, e.g. Stewart, supra n. 23, on pp. 497-504; Debelva, supra n. 23, at sec. 3.1.2.; A. Schindel and A. Atchabahian, General Report, in Source And Residence: A New Configuration of Their Principles sec. 2.4.1. (IFA Cahiers vol. 90A, Sdu Netherlands 2005), Books IBFD, at sec. 2.4.1.2; and Schön, supra n. 35, at sec. 2.2.2.1.

37 In very broad terms, it can be stated that the principle of the ability to pay underlies the taxation of residents on their worldwide income, ity to pay plays a more important role because this notion underlies the concept of income. ${ }^{38}$

What is worth stressing in discussing the fairness of a corporate tax context is the fact that, ultimately, it is never the corporation itself that bears the tax..$^{39}$ Rather, the so-called "incidence" of the tax will fall on someone else who, at the end of the day, is an individual. ${ }^{40}$ This may, for instance, be the corporation's owners (through lower dividends), workers (through lower wages), consumers (through higher prices), or the suppliers (through lower prices). ${ }^{41}$ It is not known who eventually pays the bill, and it is understood that economists also struggle to answer this question with sufficient precision. ${ }^{42}$ However, in terms of fairness perceptions, these consideration at least do not appear to matter much. Instead, it is plausible to assume that people tend to focus on the taxation of the corporation-be it the "right" perspective or not. Maybe it is here also where the actual value of the discussion lies. ${ }^{43}$ Consequently, it is broadly assumed that perceived fairness may be promoted if those corporations that earn as much pay as much income tax.

\section{The Analytical Framework}

The above sounds easier than it is. In fact, there are quite some methodological challenges that need to be overcome before entering into the analysis. For the sake of finding out whether and in as far the outcome of the Apple case can

while the benefits principle is behind the taxation of nonresidents. See, e.g., Schindel and Atchabahian, supra n. 36, at sec. 2.4.1.2.; and Schön, supra n. 35, at sec. 2.2.2.1. Certainly, the benefits principle can also legitimize residence taxation. See, e.g., K. Holmes, International Tax Policy and Double Tax Treaties: An Introduction to Principles and Application sec. 2.2.2. (IBFD 2007).

38 Schön, supra n. 35, at sec. 2.2.1.1.

39 See, for a detailed overview about this issue, including further references, M. P. Devereux, Taxing Profit in a Global Economy sec. 2.1.1. (Oxford University Press 2021).

40 See, e.g., id.

41 Id.

42 Id. See, in more detail, e.g., C. Fuest, A. Peichl and S. Siegloch, Do Higher Corporate Taxes Reduce Wages? Micro Evidence from Germany, American Economic Review 108, (2018); R. Gordon, Taxation of Investment and Savings in a World Economy, 75 American Economic Review (1986); J. C. Suárez Serrato and O. Zidar, Who Benefits from State Corporate Tax Cuts? A Local Labor Markets Approach with Heterogeneous Firms, 106 American Economic Review (2016).

43 As to the potential practical consequences that may result from the perception that the tax system is unfair, see the discussion and references provided for in chap. 1. 
contribute to inter-taxpayer equity, some outside frame of reference is needed against which this question can be analyzed.

Based on what was discussed in section 2, this benchmark would have to be the horizontally equitable tax treatment of comparable economic activity in the whole EU. That being said, it is clear from the outset that such "absolute EU-wide inter-taxpayer equity" cannot be reached. Mere disparities between member states' tax systems are, in principle, unproblematic under primary EU law. ${ }^{44}$ They also widely exist with respect to both the tax base and the tax rate. Hence, comparable economic units in different member states are typically subject to a different tax treatment. State aid rules cannot and are not intended to change that. This stems from the delineation of competences in the EU whereby member states have largely retained their sovereignty in corporate taxation.

Therefore, it would not be helpful to measure the contribution of state aid rules to inter-taxpayer equity against this background. Rather, the authors think that more insight can be gained by accepting this reality and setting a somewhat lower optimum. If we keep in mind the underlying issue at stake in the Apple case, it is thought that the "second-best inter-taxpayer equity" result lies in every transaction made by an economic unit in the EU being taken into tax consideration in precisely the same manner throughout the whole EU. It is then up to the member state to decide whether the income or expense is reflected in the tax base and the rate at which the net result is taxed. This would mean that differences in tax treatment should be attributed to only the economic activity subject to tax in different member states but not to the organizational or legal form in which it is conducted in the EU. In more concrete terms, that would result in income from economic transactions being recognized, measured, and allocated in exactly the same way regardless if it was entered into by, say, a Portuguese independent entity, the German subsidiary of a Dutch MNE, or the Irish PE of a tax resident

44 See, for a more detailed elaboration, P. Wattel, General EU Law Concepts and Tax Law, in European Tax Law sec, 3.2.7.2. (P. Wattel, O. Marres and H. Vermeulen eds., Wolters Kluwer 2019), and compare, including further reference, e.g., GE: ECJ, 12 July 2005, Case C-403/03, Egon Schempp v Finanzamt München V., [2005] ECLI:EU:C:2005:446, para. 45. See further, Commission Decision of 8 July 2009, on the groepsrentebox scheme that the Netherlands is planning to implement-C 4/07 (ex N 465/06)-underscoring in a state aid context the idea that advantages resulting from disparities are not attributable to a member state. See, for the reference, S. Douma, EUReport, in Assessing BEPS: Origins, Standards, and Responses sec. 2.2.2. (IFA Cahiers vol. 102a, Sdu Fiscale \& Financiële Uitgevers 2017). entity nowhere-while the attached tax consequences differ according to the member state in which the income is taxed..$^{45}$

Against this background, the authors will analyze how close the Apple case ${ }^{46}$ comes to this stylized "optimum of EU-wide inter-taxpayer equity". ${ }^{47}$ In this context, it is considered that an inquiry into three different dimensions of state aid is necessary. The first one concerns the reference framework. If the tax measure in question does not deviate from what is considered "normal" taxation, there is no advantage and thus no state aid. In principle, the benchmark to assess whether a tax measure is general or selective is the national tax system of each member state. However, if we assume that the general objective of transfer pricing rules in all member states is to eliminate, for tax law purposes, the effects of the absence of market forces between transactions of integrated companies and thereby to provide equal treatment of independent and integrated companies, the frame of reference could be essentially uniform in all member states. Hence, for the sake of maximizing EU-wide horizontal equity, a broad frame of reference entailing the aim of an equal treatment of independent and integrated companies must prevail in all member states. This notion of a broad frame of reference would also be in line with the general objective of state aid rules to provide competitive neutrality between economic operators, i.e., independent and integrated companies. Second, the standard used in testing for the equal treatment of the taxpayers affected must be the same in the whole EU. This means that optimizing EU-wide inter-taxpayer equity calls for a separate and distinct EU arm's length principle. ${ }^{48}$ Third, for the sake of maximizing EU-wide inter-taxpayer equity, inaccuracies that occur in applying the arm's length principle must not be tolerated.

As will be discussed in section 5, the Apple case does not always reach this optimum. At this stage, the narrow focus of the analysis will be relaxed and consideration will

45 This is, of course, save for differences in the tax base. When a member state exempts a certain item of income, it is ultimately not recognized for tax purposes. Yet, what is at interest here is the how it would be recognized had it been included. Would it, for instance, be necessary to establish an arm's length price, and how would it be established?

46 Described in sec. 4.

47 For a detailed analysis of the case from a state aid perspective, see: Mason and Daly, supra n. 20, at pp. 1317.

48 As opposed to national arm's length principles that while (i) implementing the same core idea (ensuring that transactions between related parties are priced as if they had been entered into between independent parties) and (ii) likely following the same OECD Transfer Pricing guidelines, may, at the level of detail, deviate from each other. 
be made of reasons unrelated to inter-taxpayer equity that can support not having gone that far. After all, tax policy is full of trade-offs that often occur between ensuring intertaxpayer equity, on the one hand, and the administrability of rules on the other hand ${ }^{49}$ Stated differently, the fairness conception of the person on the street is not the only thing lawmakers (can) think about.

\section{Description of the Relevant Parts of the Apple Case}

The Apple case concerned two rulings issued by Ireland in 1991 and 2007 to the two Irish subsidiaries, Apple Sales International (ASI) and Apple Operations Europe (AOE), of Apple Group..$^{50}$ Within the Apple Group, Apple Operations International is a fully owned subsidiary of Apple, Inc. Apple Operations International fully owns AOE which in turn fully owns ASI. ASI and AOE were incorporated in Ireland but were not tax residents in Ireland. ${ }^{51}$ This was because the subsidiaries' boards met in the United States, and under Irish law that applied at the time, they were nonresidents of Ireland for tax purposes. ${ }^{52}$ Both ASI and AOE had an Irish branch where all of the employees were located and were responsible for, among other things, carrying out procurement, sales, and distribution activities associated with the sale of Apple-branded products in certain regions including Europe and for the manufacture and assembly of computer products in Ireland. ${ }^{53}$

The rulings issued by the Irish tax authorities set a method for determining the amount of taxable profits in Ireland. For that purpose, the main issue was the allocation of assets, functions, and risks of ASI and AOE between the head offices and the Irish branches. Particularly, the allocation of Apple's intellectual property (IP) licences held by ASI and AOE were of crucial significance in the allocation of profits between the head offices and the Irish branches. The rulings issued by the Irish tax authorities allocated those licenses and profits therefrom outside of Ireland. ${ }^{54}$
According to the commission's primary line of reasoning, the allocation of the IP licences held by ASI and AOE outside Ireland was incorrect since the head offices had no own employees who could control and manage the IP licenses. It held that the misallocation of the IP licenses outside Ireland resulted in a selective advantage in the form of tax reduction in Ireland because the profit allocation between the head office and the Irish branches did not correspond to a reliable approximation of a market-based outcome in line with the arm's length principle they see enshrined in Article 107(1) TFEU. ${ }^{55}$

As a subsidiary line of reasoning, the commission contended that, even if the IP licences were correctly allocated outside Ireland, the rulings employed inappropriate methodological choices. It held that those choices were liable to amount to a selective advantage in that the outcome was not in line with the arm's length principle enshrined in the application of Article 107(1) TFEU. ${ }^{56}$

Finally, the commission also put forward an alternative line of reasoning. In the first place, it claimed that the Irish tax authorities departed in the rulings from the national arm's length principle for the advantage of ASI and AOE. Alternatively, in the absence of an arm's length principle under Irish law, the commission alleged that the Irish tax authorities conferred a selective tax advantage for ASI and AOE on a discretionary basis. ${ }^{57}$

The GC annulled the commission's decision on the aid measure implemented by Ireland in favor of Apple. The reason for the annulment was that the commission was unable to demonstrate the existence of a selective advantage for the purposes of Article 107(1) TFEU in favor of ASI and AOE in respect of the amount of taxable profits allocated to the Irish branches. The GC confirmed, similarly to its earlier decisions in the Starbucks and Fiat cases, that the commission may use the arm's length principle as a "tool" or "benchmark" for the purposes of examining whether the outcome accepted in the transfer pricing ruling sufficiently corresponds to a market-based outcome. ${ }^{58}$ However, in doing so, the commission cannot set aside the national tax rules, including those of allocating profits between the head office and the branch of a nonresident company that must be used for determining the normal level of taxation in Ireland. ${ }^{59}$

\footnotetext{
55 Apple, paras 37-40.

56 Apple, para. 41.

57 Apple, para. 42.

58 Apple, paras 214 and 224.

59 Apple, para. 224.
} 
With respect to the commission's primary line of reasoning, the GC held that the commission misapplied the Irish tax rules on the allocation of profits to a branch of a nonresident company that formed part of a reference system for determining normal taxation in Ireland and denied the presence of a selective advantage. ${ }^{60}$ More precisely, it held that under Irish law the commission was not entitled to allocate the income from IP licenses to the Irish branches of ASI and AOE solely because the head offices lacked any substance. ${ }^{61}$ According to the GC, the commission's analysis of the functions performed by the Irish branches with respect to controlling and managing the Apple IP licences was defective and did not support the view that the income related to them should have been allocated to the Irish branches under Irish tax law. ${ }^{62}$ Thus, the commission's attempt to allocate the profits by default to the branches because they cannot belong to the empty head office ("exclusion approach") was dismissed. ${ }^{63}$

With respect to the commission's subsidiary line of reasoning on methodological errors, the GC admitted that there were inconsistencies and lack of documentation in the tax rulings. However, in line with its argumentation in the Starbucks case, it held that methodological defects pointed out by the commission are not in themselves sufficient for establishing the presence of a selective advantage. In the same vein, the GC rejected the commission's alternative line of reasoning insofar as it was based on the use of broad discretion by the Irish tax authorities.

\section{Promotion of Equity by Means of State Aid Rules}

\subsection{Reference system and implications on equity}

By way of background, the commission's analysis in $\mathrm{Ap}$ ple of the existence of a selective advantage was based on the three-step standard for state aid. ${ }^{64,65}$ As the first step, the system of reference must be identified. The existence of an advantage is established by comparing taxation pur-

$\mathbf{6 0}$ Apple. para. 312.

61 Apple, para. 186.

62 Apple, paras 163 and 185-188.

63 Apple, para. 186.

64 See EC, 19 July 2016, Commission Notice on the Notion of State Aid as Referred to in Article 107(1) of the Treaty on the Functioning of the European Union C/2016/2946, para. 128.

65 Apple, para. 32. suant to a contested tax measure to that of "normal" taxation in the absence of the measure under the reference system. ${ }^{66}$ Second, it should be determined whether a tax measure constitutes a derogation from that system insofar as it differentiates between economic operators who, in light of the objectives intrinsic to the system, are in a comparable factual and legal situation. If the measure does not constitute a derogation from the reference system, it is not selective, and there is no advantage in the case that the examination of both the conditions overlaps as in Apple ${ }^{67}$. As the last step, in the case of a selective advantage, the issue of whether the derogation is justified by the nature or the general scheme of the reference system should be analyzed. In Apple, no justification was put forward. ${ }^{68}$

As for the correct reference system, in Apple, the GC endorsed the commission's broad view of the reference system by holding that the appropriate reference system for establishing "normal" taxation in Ireland were the ordinary rules of taxation of corporate profits in Ireland. This view is consistent with the earlier case law in Starbucks and Fiat. The GC also specified that the reference system included the rules on the allocation of profits to Irish branches even though those rules alone were not considered to be a reference system. However, those rules needed to be observed when establishing 'normal' taxation under the Irish corporate tax rules. ${ }^{69}$

It follows from the broad definition of the reference system that independent companies and group companies are in a similar factual and legal situation in light of the intrinsic objective of any corporate tax system which is to tax the profits of all companies subject to tax in the member state. In Apple, even nonresident companies were considered to be in a situation comparable to that of resident companies to the extent they are subject to tax in Ireland. ${ }^{70}$ This was the case when a nonresident company had a branch in Ireland through which it carried on trade in Ireland. The objective of the Irish ordinary corporate tax rules was the taxation of profits of all companies, whether resident or nonresident, that are subject to tax in Ireland, and the purpose of the specific provision applicable to Irish branches was to allocate to Ireland the part of the profits of a nonresident company that is attributable to the activities of its Irish branch. ${ }^{71}$

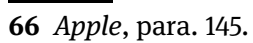
67 Apple, para. 136. 68 Apple, para. 32. 69 Apple, para. 163. 70 Apple, paras 140-142. 71 Apple, para. 163.
} 
From the perspective of inter-taxpayer equity, the main corollary from the broad reference system is that it enables the commission to rely on a member state's own national tax policy objective of providing an equal treatment of companies, whether integrated or nonintegrated and whether resident or nonresident, for corporate tax purposes. Therefore, once the member state has decided to pursue the objective of equal treatment of companies in corporate taxation, the commission has the right to supervise whether the envisaged equal treatment is sufficiently established in individual cases, particularly in the case of transfer pricing rulings, without infringing Article 107(1) TFEU. ${ }^{72}$

The above-mentioned tax policy choice is principally manifested by the adoption of the arm's length principle in the general corporate tax system of a member state, either by incorporating that principle formally in tax law or by following a de facto similar approach when allocating profits between integrated companies as was the case in Apple. ${ }^{73}$ Given that corporate tax systems of member states typically pursue this objective, they, at least currently, ${ }^{74}$ cannot deny the existence of an advantage in state aid proceedings merely based on the fact that the relevant income-producing economic activity is carried out in a different legal structure, e.g., an integrated or non-integrated company or in a different legal form, e.g., a company or a branch. Thus, with respect to the reference framework, the GC went to the optimum described in section 3. The authors think that taking this wide perspective is a remarkable contribution to inter-taxpayer equity.

72 See C. Peters, The Starbucks decision of the General Court (Cases T 760/15 and T 636/16): Stepping stone towards a sustainable solution? in CJEU-Recent Developments in Direct Taxation 2019 p. 5 (J. Lang et al. eds., 2020).

73 After analyzing Irish tax law including tax practice and case law as well as tax treaties concluded by Ireland with the US and the UK, the GC upheld the commission's view that Irish tax law applied an arm's length principle when allocating profits to Irish branches. See Apple, paras 217-220 and 225.

74 It should be mentioned that the international tax system is in the middle of being reshaped. It is possible that in the future, tax systems may include so-called formulary apportionment rules. Relevant rules are currently under discussion at the EU level (Common Consolidated Corporate Tax Base) and OECD level (Pillar 1). See EC, COM (2016) 683 final Proposal for a Council Directive on a Common Consolidated Corporate Tax Base (СССТ) (European Commission 2016); OECD, Programme of Work to Develop a Consensus Solution to the Tax Challenges Arising from the Digitalisation of the Economy, OECD/G20 Inclusive Framework on BEPS (OECD Publishing 2019).

\subsection{The choice of the arm's length principle and implications for equity}

The commission considers that the arm's length principle flowing from the state aid rules may be used as a "tool" or "benchmark" to scrutinize transfer prices in intra-group transactions. Consequently, the taxable profit of a group company pursuant to a transfer pricing ruling corresponds to a reliable approximation of a taxable profit generated under market conditions. ${ }^{75}$ Similar to Starbucks and Fiat, in Apple, the GC endorsed this view. It stated that ${ }^{76}$

[...] Article 107(1) TFEU allows the Commission to check whether that level of profit corresponds to the level that would have been obtained through carrying on that trade under market conditions, in order to determine whether there is, as a result, any mitigation of the burdens normally included in the budget of the undertaking concerned, thus conferring on that undertaking an advantage for the purposes of that provision. The arm's length principle, as described by the Commission in the contested decision, is thus a tool enabling the Commission to make that determination in the exercise of its powers under Article 107(1) TFEU.

However, most crucially, the GC also clarified that the commission cannot,

[...] however, contend that there is a freestanding obligation to apply the arm's length principle arising from Article 107 TFEU obliging Member States to apply that principle horizontally and in all areas of their national tax law.

Thus, differently from what was demanded by some schol$\operatorname{ars}^{77}$ and unlike what some have read out of the Starbucks decision, ${ }^{78}$ a separate and distinct (autonomous) EU arm's length principle does not exist. ${ }^{79,80}$ Rather, when analyzing the presence of an advantage, the commission is bound by the national definition of the arm's length principle that forms part of the reference system of the member state-and these national arm's length principles can differ between member states.

As a result, the state aid rules ensure that the arm's length price is determined in the same way with respect

75 EC, supra n. 64, para. 172.

76 Starbucks, para. 162, Fiat, para. 143, Apple, para. 214.

77 P. Wattel, Stateless Income, State Aid and the (Which?) Arm's Length Principle 44 Intertax, pp. 801 (2016).

78 Peters, supra n. 72, at p. 3.

79 Apple, para. 221.

80 See also Daly, supra n. 20; J. Monsenego, supra n. 20. As emphasized in id., also in Fiat, at para. 105, it was held that "the Commission does not, at this stage of the development of EU law, have the power autonomously to define the 'normal' taxation of an integrated undertaking, disregarding national tax rules.” 
to the economic activity conducted in a member state. On the other hand, they do not demand that this has to happen in precisely the same way in all member states. Because all member states principally adhere to the OECD guidelines, ${ }^{81}$ this is not a major practical issue. Yet, as seen in the Apple case, it can sometimes make a difference. Thus, the GC stayed below the conceivable EU-wide inter taxpayer equity optimum in this regard. The authors, however, consider this as a sensible and well-balanced approach. After all, it falls within the competence of member states to define their tax system-including the tax treatment of integrated companies vis-à-vis independent companies. The endorsement of a uniform EU arm's length principle on the grounds of Article 107(1) TFEU would arguably have resulted in the GC creating a new standard for EU-wide inter-taxpayer equity in corporate taxation. However, this could have had significant downsides from the perspective of legal certainty. ${ }^{82}$ Ultimately, the application of transfer pricing rules is already very difficult. If there was yet another layer that applies above the (national and OECD) transfer pricing rules to checking for them, actually, ensuring a reliable approximation of an arm's length outcome, it would be doubtful whether increasing complexity would still be manageable. ${ }^{83}$ This is especially so that there is nothing in EU law that would define the content of such an EU arm's length principle. ${ }^{84}$ Conceivably, the basis for such an EU principle could have been formed by the OECD transfer pricing guidelines. This solution has its charm from a practical perspective but would hardly hold up legally. Neither the EU nor all of its member states are OECD Members. For them, the OECD recommendations, which are not binding on OECD members, would not even be recommendations. ${ }^{85}$ Aside from that, Article 107(1) TFEU has had the same wording since 1957, and no EU legal act has assigned any value to the OECD transfer pricing guidelines. ${ }^{86}$

81 H. Förster \& M. Guillou, EU Report, in The future of transfer pricing ch. 1 (IFA Cahiers vol. 102b, Sdu Fiscale \& Financiele Uitgevers 2017), Books IBFD.

82 See CFE ECJ Task Force, Opinion Statement ECJ-TF 1/2020 on the General Court Decisions of 24 September 2019 in The Netherlands $v$. Commission (Starbucks) (Joined Cases C-760/15 and T-636/16) and Luxembourg v. Commission (Fiat Finance and Trade) (Joined Cases T-755/15 and T-759/15), on State Aid Granted by Transfer Pricing Rulings 60 European Taxation, p. 8 (2020). IBFD Journals (accessed 28 April 2020FE Opinion Statement (2020), (hereafter CFE Opinion Statement).

83 Id., at p. 11.

84 Id.

85 See, in more detail, id.

86 Id.

\subsection{Inaccuracies of the arm's length principle and implication on equity}

The objective of transfer pricing methods is to find a reasonable estimate of an arm's length outcome based on reliable information. Rather than a precise result, the rules only produce a range of figures, all of which may be considered as equally reliable approximations of an arm's length outcome. ${ }^{87}$ This inherent inaccuracy is also reflected in the GC's findings in Apple in the recognition that member states have a certain margin of appreciation in applying the arm's length principle. To that end, the presence of an advantage within the meaning of Article 107(1) TFEU requires that the application of the arm's length principle go beyond the "inaccuracies" inherent in transfer pricing methods. ${ }^{88}$

As long as the application of the national arm's length principle falls within the normal inaccuracies of its application, the state aid rules do not interfere with its application. This means that state aid rules impose a certain minimum standard with respect to the application of the arm 's length standard in a given member state. If so, the rationale seems to be that if the rules applied leave an area where they can still be regarded as approximating an arm's length outcome, state aid rules do not kick in. However, should the outcome go beyond normal inaccuracies, a derogation from normal taxation in the form of a selective advantage would be present. This approach comes close to finding that the state aid rules interfere with the national application of the arm's length principle only when that principle is intentionally misapplied by the tax administration of the member state in order to give an advantage to the taxpayer. ${ }^{89}$

Hence, in this respect, the GC stays far from the theoretical maximum of inter taxpayer equity. While it does set a borderline that, notably, applies EU-wide, ${ }^{90}$ it explicitly accepts differences in favor of certain economic activi-

87 See OECD (2017), OECD Transfer Pricing Guidelines for Multinational Enterprises and Tax Administrations 2017, OECD Publishing, Paris. http://dx.doi.org/10.1787/tpg-2017-en, para. 1.13.

88 Apple, para. 216.

89 This view is based on that in Fiat, paras 237, 242 and 245, where the GC refers several times to 'artificiality' of choices made in the application of the chosen transfer pricing method. See also Traversa and Flamini, supra n. 9, at 330, who point to the risk that also an unintentional wrong application of tax law might be captured by the state aid rules. For constitutional implications of such an approach, see S. Daly, The Constitutional Implications of an EU Arm's Length Principle 60 European Taxation 2, pp. 70-75 (2020).

90 Arguably, going beyond inaccuracies that are inherent in applying the arm's length standards is likely to be seen in the same or at 
ties, namely, those conducted by nonindependent companies, i.e., group companies and branches of foreign companies. In fact, as long as their transfer prices do not leave the area of inaccuracies, integrated companies can obtain tax advantages vis-à-vis independent ones. The latter cannot, by definition, shift profits into a lower taxed pocket of the same economic unit. Even if the transfer pricing of integrated companies stays within an acceptable range, the advantages may be significant, especially with respect to highly digitalized companies for which finding an accurate transfer price is particularly difficult.

Readers may have spotted a logical inconsistency in the previous paragraph-and this is precisely where the problem lies in reality. Since it is not possible to pinpoint a correct transfer price, it is also not possible to spot an inequitable deviation from it. Apart from that, tech giants such as Apple do not have an independent company counterpart. The Apple IP is unique, as may be the IPs of other tech companies. Even the OECD has recognized that transfer pricing does not work in this area. ${ }^{91}$ While this has no legal relevance in the Apple case ${ }^{92}$, it would have been manifestly absurd had the GC made an attempt to demand sticking to an allegedly correct pricing. Hence, the GC has, in the authors' opinion, sensibly accepted that the application of transfer pricing rules will lead to some approximation of a price that these rules deem acceptable. As a result, tax rulings do not become widely obsolete, as they could have become had the GC decided otherwise. ${ }^{93}$ Rather, they remain a powerful tool to introduce legal certainty into a field that suffers from a great lack of it. ${ }^{94}$

least a similar manner throughout the EU. The authors note, however, that the GC did not provide further clarification of that definition.

91 See OECD, supra n. 74, at para. 17, stating, "While there seems to be adherence among Inclusive Framework members to the principle that routine transactions can normally be priced at arm's length, there are increasing doubts that the arm's length principle can be relied on to give an appropriate result in all cases (such as, for example, cases involving non-routine profits from intangibles).” The Inclusive Framework currently consists of 139 countries. See https://www.oecd.org/tax/beps/inclusive-frameworkon-beps-composition.pdf (accessed 12 Apr. 2021).

92 One of the constituent elements of state aid is that there is a distortion of competition. However, competition is generally found to exist if the beneficiary operates in a liberalized sector of the economy where there is or could be competition. See EC, supra n. 64, para. 187. 93 Already minor deviations from an allegedly correct transfer price would have allowed the commission to challenge the ruling. The last word on its validity would then frequently be with the ECJ.

94 Compare also the rather cautious position of J. Kokott, Der EuGH als Garant fairen Steuerwettbewerbs, 6 ISR 11 (2017) who calls for finding the right balance in this respect, not least with a view to ensuring that tax rulings can still provide for adequate legal certainty.
At the same time, the GC has placed a substantial burden of proof on the commission. ${ }^{95}$ Scholars have asked whether the threshold set in the Apple case is still reasonable ${ }^{96}$ and in line with what the ECJ seems to have demanded elsewhere. ${ }^{97}$ It is arguable that should the bar be set too high for the commission, the effectiveness of state aid control could weaken.

\subsection{Other limitations on promotion of equity}

Of course, in full isolation it is also problematic from an inter-taxpayer equity perspective that the commission only chooses certain rulings in its state aid investigations. ${ }^{98}$ Yet, it is understandable for practical reasons. Furthermore, it would not be correct to focus only on tax rulings because it is also possible that a tax benefit amounting to state aid is provided "under the radar," for example, by means of informal discussions with the taxpayer as part of regular tax assessment. ${ }^{99}$ However, the challenge of providing equity not only in abstracto by law but also in concreto by enforcing the law in an equal way is by no means unique to the application of state aid rules. ${ }^{100}$

95 See, e.g., M. van Dulmen, The Netherlands Following the Recent Starbucks NL Decision 60 European Taxation, p. 4 (2020). IBFD Journals (accessed 20 April 2020). While it was not necessary in Apple to analyze the issue of burden of proof in light of inaccuracies, the earlier case law in Starbucks and Fiat dealt with the matter. Here it suffices to note that the GC concluded in Starbucks that the commission did not manage to provide enough evidence for the existence of an advantage. Starbucks, para. 516. Yet, in Fiat, the commission passed the burden of proof test. See Fiat, para. 286.

96 Monsenego, supra n. 20.

97 id., under reference to UK: ECJ, Nov. 15, 2011, Joined Cases C106/09 P and C-107/09 P, European Commission (C-106/09 P) and Kingdom of Spain (C-107/09 P) v. Government of Gibraltar and United Kingdom (Gibraltar) Gibraltar, ECLI:EU:C:2011:732.

98 It has been noted, for example, that the commission has a clear focus on those multinational companies that were already under public scrutiny via the press, NGOs, or parliaments. See R. Luja, EU State Aid Law and National Tax Rulings, IP/A/TAXE/2015-02, 12.

99 It may though be noted that, recently in the pending case Ikea, the commission decided to extend its investigations to cover not only tax rulings but also regular tax assessments. See https://ec.europa.eu/commission/presscorner/detail/en/MEX

_20_782 (accessed May 8, 2020); on this issue compare Kokott also, supra $\mathrm{n} .94$.

100 General anti-abuse rules (GAARs), to name an obvious example. Not all taxpayers that may be subject to such a rule come under audit. 


\section{Conclusions and Outlook}

In this article, the authors have examined to what extent the state aid rules contribute to inter-taxpayer equity in international corporate taxation between different legal organizations (independent companies and groups of companies) and legal forms (independent companies and branches) in which economic activities may be carried on. The examination was carried out in light of the GC's recent decision in the Apple case. The starting point was that in the absence of a full-scale harmonization of corporate taxation in the EU, no absolute EU-wide inter-taxpayer equity can be reached. However, the theoretical framework of a second-best alternative was created; a so-called "optimum of EU-wide inter taxpayer equity" that would pursue the objective of allocating income from all economic activities similarly irrespective of the organizational or legal form in which economic activities are conducted, except for the differences arising from the variances in tax basis and tax rates across the Member States.

At the outset, three different legal issues were defined related to the application of the state aid rules that would determine the extent to which they contribute to intertaxpayer equity. These issues were analyzed based on the GC's decision in Apple. First, the authors found that the endorsement of a broad reference framework that includes all companies subject to tax in a member state is a remarkable contribution to EU-wide inter-taxpayer equity. Second, it was found that the GC did not endorse an autonomous EU arm's length principle that would be distinct from the national arm's length principles of member states. To that end, the GC's approach does not maximize the contribution of state aid rules to EU-wide inter taxpayer equity in that it allows differences between the national arm's length principles. Having noted this, nevertheless, the authors found the GC's approach sensible and well balanced in view of, among other issues, the current delineation of competencies between the EU and member states in corporate taxation and issues related to legal certainty and administration. Finally, it was concluded that, based on the GC's decision, the state aid rules impose only a certain minimum standard with respect to the application of the arm's length standard in a given member state in that they require the application to fall within a range of inaccuracies inherent in the application of the arm's length principle. Seen in isolation, this is not optimal from the perspective of EU-wide inter-taxpayer equity. Yet, it is sensible in view of the nature of the arm's length principle. In addition, potential concerns were raised in relation to the strictness of the burden of proof that the GC imposed on the commission that may be liable to have a negative impact on the enforcement of state aid rules.

The authors are most curious to observe the commission's future actions in this respect. After all, there is no doubt Apple engaged in profit shifting and ultimately widely avoided paying any corporate income tax on profits it derived from its sales in Europe, and the tax ruling agreed with Ireland was an important part of Apple's overall tax planning structure. ${ }^{101}$ There are several options for the commission. On the one hand, it can appeal against the GC's decision, which it had already decided to do. In this regard, it may try to uphold its sui generis EU arm's length standard by means of which it could try to apply the exclusion approach. ${ }^{102}$ Should the GC's sentence be upheld by the ECJ, the commission could start again and launch a new investigation whereby it could concentrate on different factors. Parts of the literature seem to see better odds for the commission should it challenge the Irish residency provisions that are said to have been geared toward allowing MNEs like Apple to create stateless income. ${ }^{103}$

The authors further stress that although the commission lost the Apple case at the GC level, the fact that it won the question with respect to the reference framework is not to be underestimated. Apart from that, it seems that the commission has established itself as a serious player in the international tax arena. The launch of the state aid investigations at the very least played a role in Ireland in abolishing its residency rules. This means that such a tax structure could not exist today. ${ }^{104}$ This is at least a small comfort for the person on the street.

101 For a description of the tax planning structure, see Mason, supra n. 52, at pp. 736-737; A. Ting, iTax-Apple's International Tax Structure and the Double Non-Taxation Issue, 59 Brit. Tax Rev. 1 (2014).

102 Mason and Daly, supra n. 20, at p. 1329.

103 Compare, for example, the notes by Daly, supra n. 20, and Monsenego, supra n. 20: see, on the Irish rules, e.g., Mason and Daly, supra n. 20, at pp. 1326 et seq.

104 Mason and Daly, supra n. 20, at pp. 1331-1332. In addition, given that aggressive tax planning and tax avoidance have gained wide public attention and keeping in mind that the payday for the COVID-19 crisis will come, the authors would not rule out that the commission will indeed take the bull by its horns and choose the nuclear option of invoking Article 116 TFEU for direct tax purposes. 